\title{
Body Weight Gain Reason Not Done
}

National Cancer Institute

\section{Source}

National Cancer Institute. Body Weight Gain Reason Not Done. NCI Thesaurus. Code C119770.

The explanation given as to why body weight gain was not assessed. 